\title{
UNDERSTANDING HOW A LAW CLINIC CAN CONTRIBUTE TOWARDS STUDENTS’ DEVELOPMENT OF PROFESSIONAL RESPONSIBILITY
}

\author{
Ann Thanaraj*
}

\section{Cumbria University, UK}

\begin{abstract}
There is rich international literature spanning over decades giving valuable insights into the educational benefits of Clinical Legal Education (CLE), however there is little in the way of empirical data evaluating the link between utilizing CLE to develop specific skills. This paper aims to discover the link between CLE as a learning methodology and the extent to which students become more aware of professional responsibility skills after a clinical experience. The study employed a phenomenographic methodology to evaluate the variations in student learning. The findings suggest that students believe they have developed a greater sense of awareness and learning of a variety of lawyering skills and a greater awareness of values and characteristics of a competent lawyer through the clinical experience.
\end{abstract}

\section{INTRODUCTION}

Clinical Legal Education (CLE) is a popular teaching and learning methodology used by law schools across a number of jurisdictions. ${ }^{1}$ There is rich international literature spanning over decades on the educational value of the use of CLE ${ }^{2}$ however, in the

\footnotetext{
*Ann Thanaraj is Principal Lecturer in Law at the University of Cumbria

${ }^{1}$ One of the leading advocates of CLE is Neil Gold in Gold, N. (2015) 'Clinic is the Basis for a Complete Legal Education: Quality Assurance, Learning Outcomes and the Clinical Method', International Journal of Clinical legal education, Vol. 22, No. 1, available at:

http://www.northumbriajournals.co.uk/index.php/ijcle/issue/view/53 and Mary Ann Noone in Noone, M.A., (2013) 'Time to rework the brand 'Clinical Legal Education', International Journal of Clinical Legal Education, Vol. 19, No.1 available at: http://www.northumbriajournals.co.uk/index.php/ijcle/issue/view/13

${ }^{2}$ The literature on CLE and its educational benefits are in abundance. Examples of pioneering work are from Grimes, R. (1995) “Legal Skills and Clinical Legal Education” Web Journal of Current Legal
} 
Best Practice report of 2007,3 Professor Stuckey, a distinguished professor emeritus of

CLE, recommended that the actual effectiveness of CLE needs to be assessed to help determine what students are learning. ${ }^{4}$

Existing literature suggests that the clinics can appropriately facilitate the learning of professional responsibility. ${ }^{5}$ This paper aims to discover the link between CLE as a learning methodology and the extent to which students become more aware of the knowledge, skills and the values and behaviour of professional responsibility. ${ }^{6}$

A phenomenographic empirical study will be employed to determine:

1. How students recognise and understand their learning and acquisition of knowledge, skills and character building during clinical experience?

2. What are the challenges students face during a clinical experience?

Issues Vol. 3; MacCrate, R. (2004) "Yesterday, Today and Tomorrow: Building the Continuum of Legal Education and Professional Development" Clinical Law Review, Vol. 10, Spring edition; Giddings, J. (2008) 'Contemplating the Future of Clinical Legal Education', Griffith Law Review Vol. 15, p.15, available at:

https:/www.researchgate.net/publication/29469123 Contemplating the Future of Clinical Legal E ducation; Hall J., Kerrigan K., (2011) ‘Clinic and the Wider Law Curriculum', International Journal of Clinical Legal Education, Vol. 15, available at:

http://www.northumbriajournals.co.uk/index.php/ijcle/issue/view/15;

${ }^{3}$ Stuckey et. al. (2007) 'Best Practices for Legal Education', Clinical Legal Education Association, available at: http://www.cleaweb.org/Resources/Documents/best practices-full.pdf

${ }^{4}$ Stuckey, R. (2006) 'Can We Assess What We Purport to Teach In Clinical Law Courses? International Journal of Clinical Legal Education, Vol 9, available at:

http://journals.northumbria.ac.uk/index.php/ijcle/article/view/85

${ }^{5}$ Foley et al. (2012) 'Teaching professionalism in legal clinic - what new practitioners say is important', International Journal of Clinical Legal Education, Vol 17, available at:

http://www.northumbriajournals.co.uk/index.php/ijcle/issue/view/8

${ }^{6}$ This study is not claiming to establish that professional skills are developed by Clinical Legal Education 
3. Using the findings from the students' awareness and learning, to offer some reflections on how to use clinics constructively to capture the development of professional responsibility.

A phenomenographic approach to an empirical study in CLE is a new method of identifying and analysing data from students who agreed to participate in this study. It is envisaged that employing this methodology in this subject discipline will help academics go further in considering the variations in student learning within a clinical curriculum. The methodology section will offer details of how the study was constructed and the methods employed to arrive at the findings of the study.

\section{WHY TEACH USING CLINICS?}

The underlying pedagogy used in designing a CLE curriculum maps into a constructivist experiential learning framework. The MacCrate report explains that the value of undertaking actual legal work exposes students to the "...essential values of the legal profession: provision of competent representation; promotion of justice, fairness, and morality; continuing improvement of the profession; and professional self-development."

This means through participation in the clinical experience, students will have the opportunity to develop their existing knowledge and understanding of the

\footnotetext{
${ }^{7}$ American Bar Association section of Legal Education and admissions to the bar - An educational continuum, report of the task force on law schools and the profession: Narrowing the Gap (1992), p.207, available at:

http://www.americanbar.org/content/dam/aba/publications/misc/legal education/2013 legal educati on and professional development maccrate report).authcheckdam.pdf Also known as the MacCrate report.
} 
substantive law by building on previous learning, application and understandings of the law to solve client problems. ${ }^{8}$ Alongside this, it has been suggested that clinical education will enable students to gain experience in performing various lawyering activities $^{9}$ such as legal research, managing their case, interviewing clients, gathering facts and preparing advice and negotiating on behalf of a client, and perhaps even attending court with a client which are commonly present in many CLE experiences. Through this, students will learn to integrate knowledge of substantive law and its application in practice using the experience gained. ${ }^{10}$

The benefits and opportunities of learning within the constructive experiential framework can be utilized by encouraging students to reflect on the experience and opportunities. When reflection takes place, it facilitates awareness of learning, awareness of skills development, and an awareness of areas for improvement. ${ }^{11}$ Learning through this process become more focused, personalised and at a deeper level, which helps to promote development of personal and professional values,

\footnotetext{
${ }^{8}$ Moliterno, J. (1996) ‘Legal Education, Experiential Education, and Professional Responsibility', Vol. 38, William and Mary Law Review, p.78, available at: http://scholarship.law.wm.edu/cgi/viewcontent.cgi?article=1657\&amp;context=wmlr Cruess \& Cruess (2012) 'Teaching Professionalism: General Principles' Medical Teacher, Vol.4(4), p.259 available at: http://www.ncbi.nlm.nih.gov/pmc/articles/PMC3987476/

${ }^{9}$ As discussed on page 9 on identifying professional responsibility

${ }^{10}$ Much literature on CLE discusses the integration of substantive law with actual application of the law in practice as a key benefit of CLE. This is true. However, in order for students to gain a useful learning experience from CLE, they will need to be equipped with the theory of various lawyering skills and lawyer values and characteristics so that this knowledge can be utilized and built upon during the CLE experience.

${ }^{11}$ Leading literature on reflecting in professional practice is from Schon, D. The Reflective Practitioner: How Professionals Think In Action (1983) New York: Basic Books, p.7
} 
attitudes, and beliefs, ${ }^{12}$ with students taking a greater role and responsibility for their learning, preparing for continual lifelong learning and professional development. ${ }^{13}$ Using the insight of students' learning obtained through the phenomenographic methodology, this study seeks to test if students believe they have developed the skills and values of professional responsibility. It must be clarified that this study was unable to test if the students have actually gained or improved these skills.

\section{GAPS IN THE LITERATURE}

CLE has been advocated as the gold standard for delivering a successful legal education curriculum. ${ }^{14}$ The MacCrate report emphasized the benefits of CLE recommending law schools to "determine how its school can best improve the process of helping students acquire the skills and values that are important in the practice of law, . . ${ }^{15}$ The Carnegie report echoes this central role and value of clinics explaining that '...clinics have made, and continue to make, an invaluable contribution to the entire legal enterprise. They are a key component in the development and advancement of skills and values throughout the legal profession". ${ }^{16}$ Through successful advocating of its' effectiveness

\footnotetext{
${ }^{12}$ Clubb, K. (2014) ‘Masters of our Destiny - The Integration of law clinic into post graduate Masters provision. International Journal of Clinical Legal Education, Vol. 20 (2), available at: http://www.northumbriajournals.co.uk/index.php/ijcle/issue/view/11

${ }^{13}$ When students undertake learning in the context of a lawyer's role with appropriate supervision and timely feedback this create a rich learning environment. For discussion on CPD in professional setting, the GMC's report on The Effectiveness of Continuing Professional Development - Final Report, 2010 College of Emergency Medicine is available at: http://www.gmcuk.org/Effectiveness of CPD Final Report.pdf 34306281.pdf

${ }^{14}$ Gold, N. (2015), supra 1

15 The MacCrate report (2002) supra 7, Recommendation 8

${ }^{16}$ Sullivan et al. (2007) 'Educating lawyers: Preparation for the profession of law', The Carnegie Foundation for the Advancement of Teaching, p. 187-88, available at:
} 
and educational value, CLE is a teaching and learning methodology used widely across law schools across the globe. There are also conferences and forums for academics to share best practices in CLE. ${ }^{17}$

It has been argued that assumptions are made about the educational benefits of CLE to contribute towards a student's skills and professional development. ${ }^{18}$ This is based on the lack of testing and evidence of data showing actual learning and development through CLE. ${ }^{19}$ It must be noted that the literature on CLE is rich, encouraging and offers an extensive amount of support for new clinicians and law schools new to CLE, ${ }^{20}$ describing how it works, different models of CLE and the skills gained through a CLE study. However, despite the support for CLE, there is little evidence in existing literature to help academics understand how, why and in what context clinics can deliver the educational benefits and to explain the relationship between CLE and the practical and professional development of law students.

\footnotetext{
http://archive.carnegiefoundation.org/pdfs/elibrary/elibrary pdf 632.pdf Also known as The Carnegie report

${ }^{17}$ Conferences such as the International Journal of Clinical Legal Education conference held annually across the globe, and forums such as the National Institute for Teaching Ethics and Professionalism set up by Georgetown University and in the UK by City Law School are leaders in the areas of CLE and professional responsibility..

${ }^{18}$ Bergman, P. (2003) 'Reflections on the US legal education', International Journal of Legal Professions, Vol 10, No. 1, p,112.

${ }^{19}$ Evans A. \& Hyams R. (2008) 'Independent Evaluations of Clinical Legal Education Programs: Appropriate Objectives and Processes in an Australian Setting', Vol 17, No. 1, Griffith Law Review. p.14.

${ }^{20}$ There is a compilation of literature on various aspect of CLE, see Ogilvy \& Czapanskiy, (2005) 'Clinical Legal Education: An Annotated Bibliography' Clinical Law Review, Special Issue No. 2, available at: http://faculty.cua.edu/ogilvy/Biblio05clr.htm. Note however that the compilation is approximately 11 years old, although this discussions are still relevant today.
} 
It has been questioned whether it is the CLE itself or whether some other form of teaching methodology integrated into the CLE programme of study might help contribute to professional responsibility. ${ }^{21}$ Bergman's work on Clinical Legal Education is a useful starting point to this research paper.

Two major studies on CLE have taken place. First, in 2008, an insightful study by The Predictors of Successful Lawyering Project ${ }^{22}$ surveyed members of the legal profession and judiciary, law academics, students and clients on lawyering skills and competencies. Although this study was most valuable in identifying the key components of effective lawyering, it did not address the mechanisms through which legal education can support the acquisition of these skills (thereby making a case for or against clinics). ${ }^{23}$

The year after, another study by an Australian law school ${ }^{24}$ surveyed students in the third year of the law programme and followed their professional journey for two years after graduation and found that students who received clinical training were more often than not more willing to undertake pro bono work than those without clinical

\footnotetext{
${ }^{21}$ Bergman, P. (2003), supra 19. Also see discussion in Evans A. \& Hyams R. (2008) 'Independent Evaluations of Clinical Legal Education Programs: Appropriate Objectives and Processes in an Australian Setting', Vol 17, No. 1, Griffith Law Review, p.15

${ }^{22}$ Shultz, M. \& Zedeck, S., (2009) 'Predicting Lawyer Effectiveness: A New Assessment for Use in Law School Admission Decisions', available at: http://papers.ssrn.comlsol3/papers.cfm?abstractjid=1442118.

${ }^{23}$ Ibid., p.26-27. The studies show that there are 26 effectiveness factors in eight umbrella categories intellectual and cognitive; research and information gathering; communication; planning and organizing; conflict resolution; client and business relations - entrepreneurship; working with others; and character.

${ }^{24}$ Evans, A. \& Palermo, J., (2009) 'Lawyers and Ethics in Practice: The Impact of Clinical and Ethics Curricula on Lawyers' Ethical Decision-Making', Monash Univ. Faculty of Law, Legal Studies Research Paper No. 2007, available at http://ssrn.com/abstract=1349427
} 
experience during law school. ${ }^{25}$ Both these studies are really useful as they offer valuable insight into how clinical experience may have helped shape a future lawyer but they have yet to investigate any data from which to establish a relationship between the clinical experiences and the acquisition of lawyering skills and development of professional responsibility.

Aaronson' ${ }^{26}$ paper had set out to establish good lawyering skills and concluded that the facilitation of cognitive and emotional development in students will provide them with a solid foundation to become lawyers who are able to fulfil key responsibilities. Similarly, Breger's ${ }^{27}$ paper featured a law school's effort to teach professionalism, using a variety of techniques and covered a variety of subject matter and $\mathrm{O}^{\prime} \mathrm{Grady}^{\prime} \mathrm{s}^{28}$ paper questions whether collaborative learning in a law school clinic adequately prepares students for practice. All this rich research is valuable in discussing the benefits of CLE, however the research does not provide insight into the validity of clinics through a methodological framework within the context of their research questions. Neither do the papers investigate and establish the extent clinical experience serves in the development of professionalism and lawyering skills.

\footnotetext{
25 Ibid.

${ }^{26}$ Aaronson, M., (2002) 'Thinking Like a Fox: Four Overlapping Domains of Good Lawyering', Clinical Law Review, Vol.9, available at: http://repository.uchastings.edu/faculty scholarship/7

${ }^{27}$ Breger, M., et al. (2004), 'Teaching Professionalism in Context: Insights from Students, Clients, Adversaries and Judges', South Carolina Law Review, Vol. 55, pp. 303-347, available at SSRN: http://ssrn.com/abstract $=566061$

${ }^{28}$ Gage, C, (1998) ‘Preparing Students for the Profession: Clinical Education, Collaborative Pedagogy, and the Realities of Practice for the New Lawyer' Clinical Law Review, Vol. 4, p.485, available at: https://litigationessentials.lexisnexis.com/webcd/app?action=DocumentDisplay\&crawlid=1\&doctype $=$ cite $\&$ docid $=4+C$ linical + L.+Rev.+485\&srctype $=$ smi\&srcid=3B15\&key=4c8ba8ea21344d37b5dcc1a2c2684354
} 
Recent work from Engler ${ }^{29}$ pays homage to the MacCrate Report and most helpfully provides us with a roadmap on how to use the report to develop competent and ethical lawyers. Hyams'30 work on teaching students to act like a lawyer investigates the type of lawyer we want students to act like and leads the current literature on lawyering skills, values and characteristics of professional responsibility. However empirical research on the relationship between CLE and professional responsibility could have added some useful insights into why the characteristics identified were relevant for professional practice.

\section{IDENTIFYING PROFESSIONAL RESPONSIBILITY}

The formation of professional responsibility in law students has been of global interest amongst the legal professions. ${ }^{31}$ Major work in this area include the MacCrate Report

\footnotetext{
${ }^{29}$ Engler, R., (2003) 'From 10 to 20: A Guide to Utilizing the MacCrate Report over the Next Decade', Vol. 23 Pace Law Review, p.519, available at: http://digitalcommons.pace.edu/plr/vol23/iss2/4 ${ }^{30}$ Hyams, R. (2008) 'On teaching students to 'act like a lawyer': What sort of lawyer?', International Journal of Clinical Legal Education, Vol. 13, available at: http://journals.northumbria.ac.uk/index.php/ijcle/article/view/65

${ }^{31}$ The most insightful work on the knowledge, skills and characteristics of a professionally responsible lawyer is seen in the MacCrate report, the CLEA Best Practice report and the Carnegie report. Examples of professional responsibility discussions across the jurisdictions include:

- England and Wales - Solicitors Regulation Authority, Legal Practice Course: Outcomes 2011, Version 2, available at: www.sra.org.uk/documents/students/lpc/Outcomes-Sept2011.pdf Furthermore, the 2013 report on the Legal Education and Training Review can be found at: http://letr.org.uk/

- Canada - Federation of Law Societies of Canada, Task Force on the Canadian Common Law Degree, Final Report available at: http://www.flsc.ca/ documents/Common-Law-DegreeReport-C.pdf and http://www.flsc.ca/en/national-admission-standards/
}

- New Zealand - Institute of Professional Legal Studies, Graduate Competencies, available at: http://www.ipls.org.nz/for-employers 
which sets out ten fundamental lawyering skills ${ }^{32}$ and four professional values ${ }^{33}$ that "every lawyer should acquire before assuming responsibility for handling a legal matter"34 as part of a standard legal education. ${ }^{35}$ The report identified that providing competent representation to clients, promoting justice with fairness, and improving oneself ${ }^{36}$ are essential professional traits of lawyers. ${ }^{37}$ In addition, another major work in this area, the CLEA Best Practice report ${ }^{38}$ also called for law graduates to demonstrate competency and professionalism in resolving legal problems.

In response to the discussions ${ }^{39}$ surrounding lawyer proficiencies and professionalism within the law curriculum in England and Wales, ${ }^{40}$ a range of 'Day one outcomes'

\footnotetext{
${ }^{32}$ As set out by the MacCrate report, the ten fundamental lawyering skills the report identified are: problem solving; legal analysis and reasoning; legal research; factual investigation; communication; counselling; negotiation; litigation and alternative dispute resolution; organization and management of legal work; and recognizing and resolving ethical dilemmas - The MacCrate report, supra 7, p.123 ${ }^{33}$ The four fundamental values set out in the MacCrate report are: provision of competent representation; striving to promote justice, fairness and morality; striving to improve the profession; and professional self-development - The MacCrate report, supra 7, p.140

${ }^{34}$ The MacCrate report, supra 7, p.7

${ }^{35}$ See also Engler R, The MacCrate Report Turns 10: Assessing Its Impact and Identifying Gaps We Should Seek to Narrow, (2001) 8 Clinical Law Review. p.115

${ }^{36}$ MacCrate, R. (2000) 'Professional Values in the Practice of Law', William Mitchell Law Review Vol 27(2) available at: $\underline{\mathrm{http}} / / /$ open. $m i t c h e l l h a m l i n e . e d u / c g i / v i e w c o n t e n t . c g i ?$ article $=1776 \&$ context $=\mathrm{wmlr}$ ${ }^{37}$ The 2007Carnegie report discussed the development of a professionalism as 'conceptual knowledge, skills and moral discernment and concludes that in legal education 'professionalism, social responsibility, or ethics draws to the foreground the purposes of the profession and the formation of the identity of lawyers guided by those purposes' (The Carnegie report, supra, 16, p3)

${ }^{38}$ Stuckey, R. (2007) ‘Best Practices for Legal Education' available at:

http://www.cleaweb.org/Resources/Documents/best practices-full.pdf

${ }^{39}$ The Solicitors Regulation Authority has undertaken a number of reviews and consultations. See: Law Society Consultation: Training Framework Review (London, Law Society, 2001)

- The first consultation was on the inclusion of ethics into the curriculum (Consultation in 2001, paragraph 21-22)

- The second consultation was on understanding of professional responsibilities, ethics and values required of a solicitor (Consultation in 2003, paragraph 87)

- The third consultation was on a trainee solicitor's core values and skills (Consultation in 2005, paragraph 73)

${ }^{40}$ An independent review by the Law Society found that "It is difficult to see how lawyers can be expected to be responsible/feel accountable when they are taught nothing of the history of their own profession, its challenges and aspirations...some deeper understanding of the professional project of lawyering ... It might also
} 
were developed setting out the requirements of knowledge, attributes and ethics expected of a newly qualified solicitor, ${ }^{41}$ including appropriate behaviours, integrity, sensitivity to clients and others ${ }^{42}$ and the ability to recognise and resolve ethical dilemmas. ${ }^{43}$

In addition, the Quality Assurance Agency (QAA) benchmark standards of 2015 for Law expects that "... a law graduate is far more than a sum of their knowledge and understanding, and is a well skilled graduate with considerable transferable generic and subject-specific knowledge, skills and attributes." 44

There are a number of research papers from law academics on teaching professional responsibility. For example, Noone and Dickson ${ }^{45}$ identify that a professionally responsible lawyer is someone who fulfils the duties attached to a fiduciary

more generally be argued that development of an understanding of the ethical basis of law (not just lawyering) is also a necessary prerequisite of vocational training in professional ethics and conduct..." - See reference made by Boon, A., \& Webb, J., (2008) ‘Legal Education and Training in England and Wales: Back to the Future?', Journal of Legal Education, Volume 58, Number 1, available at:

http://letr.org.uk/references/storage/U7RC3RR2/Boon\%20\%26\%20Webb,\%20back\%20to\%20the\%20fut ure.pdf

${ }^{41}$ A new framework for work based learning: Consultation - Annex 1 - Day one outcome - "Knowledge of ... the rules of professional conduct (including the accounts rules) ....understanding of ... the values and principles on which professional rules are constructed, available at:

http://www.sra.org.uk/solicitors/qlts/day-one-outcomes-table.page. For specific attributes see

Outcome $\mathrm{C}$ and $\mathrm{F}$

${ }^{42}$ Ibid. Outcome C

${ }^{43}$ Ibid. Outcome D

${ }^{44}$ These can be found at http://www.qaa.ac.uk/en/Publications/Documents/SBS-Law-15.pdf which sets out the key characteristics and skills a graduate of law should be capable of demonstrating. Some of these include intellectual independence, self-management, awareness of principles and values of law and justice, and of ethics, study in-depth and context of substantive areas of law, ability to conduct self-directed research, ability to interpret a range of data, ability to tolerate ambiguity and deal with uncertainty in law, ability to produce a synthesis of relevant literature, critical judgement of the merits of particular arguments, ability to apply knowledge and understanding to offer evidenced conclusions, ability to communicate and engagement with their own personal and professional development, and academic integrity" - Benchmark standards, section 2.4, p.7

${ }^{45}$ Dickson J \& Noone M.A, Teaching Towards a new Professionalism: Challenging Law Students to Become Ethical Lawyers (2001) Vol.4(2) Legal Ethics p.127 
relationship ${ }^{46}$ through skills such as actively engaging in serving the community, effective communication; identifying ethical issues and using the law justly and fairly. ${ }^{47}$

Hyams $^{48}$ explains that autonomy demonstrated through an independent and selfdirected manner is a necessary skill of professional responsibility. The ability to make sound judgements, ${ }^{49}$ through practical wisdom, a process of imagination, careful deliberation, and intuitive comprehension ${ }^{\prime 50}$ is one that is not limited to legal matters alone. ${ }^{51}$ Good lawyering and professionalism require an ongoing process of understanding personal limitations by reflecting on experience, ${ }^{52}$ to continually improve through a lifelong learning and professional development..$^{53}$

From reviewing the literature and through a degree of consensus from this and my own views, I have developed a range of learning outcomes in table 1 below which could be incorporated into clinical modules to help students learn and demonstrate professional responsibility. Within this study, these learning outcomes will assist in forming a basis for a definition of professional responsibility which will be used to

\footnotetext{
${ }^{46}$ Ibid.

${ }^{47}$ Ibid.

${ }^{48}$ Hyams, R. (2008), supra 30.

${ }^{49}$ Ibid.

Further, the CLEA Best Practice Report provides a comprehensive list of "good lawyer" traits which includes the ability to make competent judgements: integrity; honesty; diligence; fairness; courage; wisdom; compassion and balance - The Best Practice report, supra 50, p.51-53

${ }^{50}$ Eberle E. J. Three Foundations of Legal Ethics: Autonomy, Community, and Morality (1993) 7 Georgetown Journal of Legal Ethics, p.123.

${ }^{51}$ Sampford C. \& Blencowe S. Educating Lawyers to be Ethical Advisers in Economides, Kim (ed), Ethical Challenges to Legal Education \& Conduct, (Hart Publishing Oxford 1998) p.319.

${ }^{52}$ Hyams, R. (2008), supra 30

${ }^{53}$ Ibid.
} 
test students' awareness of their development of professional responsibility through

a clinical experience and to determine the extent to which students feel they have

become more aware of what these skills are and what level of proficiency is required.

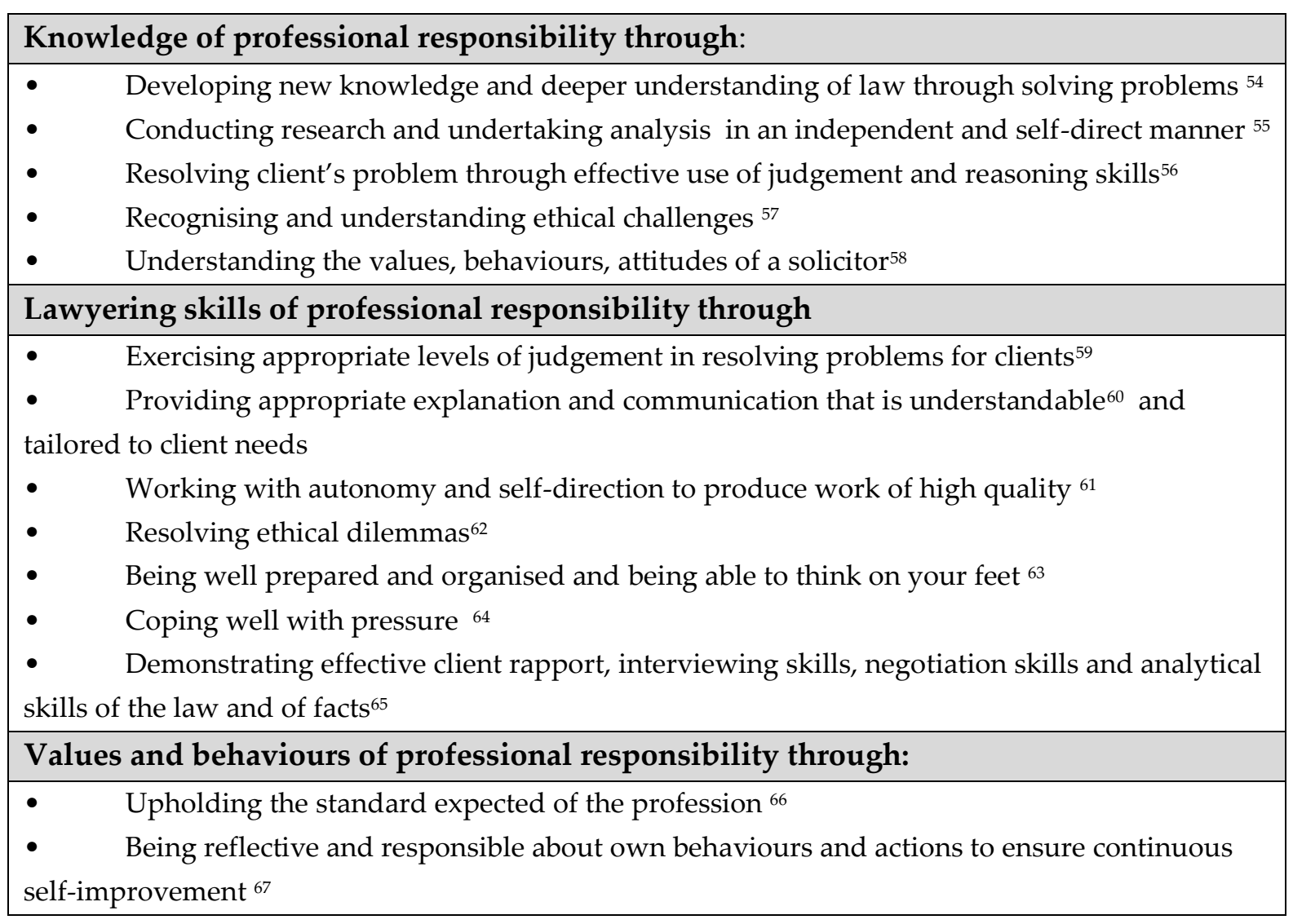

${ }^{54}$ The MacCrate report, supra 7; Noone, M. and Dickson, J, supra 45

${ }_{55}$ Hyams, R. (2008), supra 30

56 Ibid.

${ }^{56}$ The MacCrate report, supra 7; Noone, M. and Dickson, J, supra 45

${ }^{57}$ The MacCrate report, supra 7; Hyams, R. (2008), supra 30

${ }^{57}$ The MacCrate report, supra 7 and the SRA Education and Training Committee Day one outcomes April 2007

${ }^{58}$ SRA Education and Training Committee Day one outcomes April 2007

${ }^{59}$ Hyams, R. (2008), supra 30

${ }^{60}$ The MacCrate report, supra 7; Noone, M. and Dickson, J, supra 45

${ }^{61}$ Hyams, R. (2008), supra 30

${ }^{62}$ The MacCrate report, supra 7; Noone, M. and Dickson, J, supra 45; SRA Education and Training

Committee Day one outcomes April 2007

${ }^{63}$ Hyams, R. (2008), supra 30

${ }^{64}$ The MacCrate report, supra 7; Noone, M. and Dickson, J, supra 45

${ }^{65}$ SRA Education and Training Committee Day one outcomes April 2007

${ }^{66}$ The MacCrate report, supra 7 and the SRA Education and Training Committee Day one outcomes April 2007, and Noone, M. and Dickson, J, supra 45 - Striving to promote justice, fairness and morality ${ }^{67}$ Hyams, R. (2008), supra 30 
Showing integrity and sensitivity towards clients and others ${ }^{68}$

- $\quad$ Exerting judgement in a manner that uses the law justly and fairly 69

- $\quad$ Raising ethical concerns where appropriate ${ }^{70}$

- $\quad$ Fulfilling the duties of the fiduciary relationship ${ }^{71}$

Table 1: Professional responsibility learning outcomes

This framework of learning outcomes will be utilized throughout the study to:

a) Assess whether students believe their experience of clinic contributed to their development of the knowledge and/or skills and/or character development of professional responsibility;

b) Determine the extent to which students believe they have become more aware of what professional responsibility is and whether the level of proficiency required;

c) Draw out and label the themes from the data to assist in determining students' awareness of professional responsibility;

d) Using the findings from the students' awareness and learning, to offer some reflections on how to use clinics constructively to capture the development of professional responsibility;

\section{THE STUDY AND METHODOLOGY}

This study features a module in which law students participate in the representation of actual clients under the supervision of a tutor/solicitor.

A phenomenographic methodology can be used systematically to explore the different participants' experiences and identify their understanding and meanings of

\footnotetext{
${ }^{68}$ SRA Education and Training Committee Day one outcomes April 2007 - Being honest and trustworthy

Showing respect for the client

${ }^{69}$ Hyams, R. (2008), supra 30 and Noone, M. and Dickson, J, supra 45

${ }^{70}$ The MacCrate report, supra 7; Noone, M. and Dickson, J, supra 45 and the SRA Education and

Training Committee Day one outcomes April 2007

${ }^{71}$ Noone, M. and Dickson, J, supra 45
} 
the phenomenon being studied..$^{72}$ A phenomenographic method is relevant for this study as the research aims to study students' lived experiences and conceptions of professional responsibility. The existence of variation in experiences is founded on the hypothesis that individuals experience the world in unique and different ways. ${ }^{73}$

The data was collected from 36 self-selecting participants and the breadth of the representation of the participants across the second and third year programmes has provided 'useful insight' into the different ways in which CLE had facilitated awareness and development of professional responsibility in students.

The findings from this study will be analysed to find evidence of students' awareness of professional responsibility (as outlined in the learning outcomes in table 1) which students feel they may have developed after a clinical module. From these findings, it is hoped that we will be able to better understand and improve the use of clinics to draw out the desired learning outcomes of professional responsibility most effectively.

Sampling, interviewing and transcription

A pool of 36 participants was drawn from a second and third year class in the law programme through a self-selection process. The second year participants had undertaken nine months of a CLE curriculum and the third year participants have had

\footnotetext{
${ }^{72}$ Marton, F. (1986). Phenomenography - A research approach investigating different understandings of reality. Journal of Thought, Vol. 21, p.28-49.

${ }^{73}$ Säljö, R. (1988). Learning in educational settings: Methods of inquiry. In P. Ramsden (eds.), improving learning: New perspectives. London: Kogan Page, pp.32-48;

Marton, F., Pong, W. Y. (2005) 'On the unit of description in phenomenography', Higher Education Research and Development Vol. 24, p.335
} 
a further three to six months of work experience with law firms during the course of their study at the time of data collection. The study did not seek to explore whether the additional experience would have facilitated a more enhanced development of professional responsibility.

Each interview lasted around 30 minutes. The dialogue took place in a free-flowing joint discussion between the researcher and the participant. The dialogues were conducted by myself as the researcher and clinical tutor. Each interview began with a clear explanation of the purpose of the research and what I hope to learn from the discussion. Confidentiality and anonymity was assured. I adopted an informal intentional-expressive approach ${ }^{74}$ to the dialogue, where participants were asked to discuss their experience on the clinical module, in particular, for me to draw out any awareness and development of professional responsibility skills.

Follow up questions are asked to encourage participants to reflect on and confirm the intended meanings in the expressions that they have used, thereby helping to establish objectivity to the interviewees' perspectives, ${ }^{75}$ and minimizing any assumptions or influence of the interviewer. Further, there were five open-ended ${ }^{76}$ questions which participants were asked towards the end of the conversation to encourage them to reflect and discuss aspects of developing professional responsibility. ${ }^{77}$ This also

\footnotetext{
${ }^{74}$ Anderberg, E. (2000) ‘Word meaning and conceptions: An empirical study of relationships between students' thinking and use of language when reasoning about a problem Instructional Science', Vol.28, available at: http://www.springerlink.com/content/182142t6356h3m31/

75 Svensson et al. (2006a)

${ }^{76}$ Anderberg, E. (2000) Supra 76

77 Walsh, E. (2000) ‘Phenomenographic analysis of interview transcripts'. In Bowden, J., Walsh, E. (eds) Phenomenography. Melbourne: RMIT University Press, 19-33.
} 
helped with providing some structure to the dialogue especially when students weren't too sure on what aspects to discuss.

The questions were:

a) In your view, what are the learning benefits of CLE?

b) Having completed the CLE module with the reflective portfolio, what do you understand by the term 'professional responsibility'?

c) Can you give examples of ways in which your CLE experience has facilitated your knowledge of professional responsibility?

d) Can you give examples of ways in which your CLE experience has facilitated your professional responsibility skills?

e) Can you give examples of ways in which your CLE experience has given you the opportunity to gain and demonstrate the values and behaviours of someone who is professionally responsible?

It is acknowledged that these questions make the assumption that there is a link between the CLE experience and professional responsibility, however questions (a) and (b) are addressed first to determine whether the participant is able to articulate an awareness of professional responsibility before the more direct questions to establish link is discussed in questions (c) to (e).

In a phenomenographic study, critics may question the credibility of the data gathered because of the conversation between the researcher themselves with the participant and the potential lack of independence from the study. I was also mindful of the potential differences in the use of language and meaning in interview data. As such, there was continual clarification of intended meanings through follow up questions 
so that assumptions were minimised. ${ }^{78}$ I avoided offering alternative phrases or more accurate expressions; instead I listened attentively. Throughout the interviews, I was thoughtfully analysing the data I was hearing, to confirm the categories identified from previous dialogues, to discover emerging categories, and sometimes to reject some categories which I had previously identified. ${ }^{79}$

Practitioners of this methodology have warned that the written notes could change the intended meanings of participants ${ }^{80}$ and could run the risk of misinterpretation of the data. ${ }^{81}$ In this study, the dialogues were recorded by way of written notes as exact as possible, including expressions and clarified intended meanings, ${ }^{82}$ which was crucial, since the categories of description were to be constructed from the participants' experiences gathered from this process. There may be criticism over the possibility of bias and assumptions being made about the true intent of the notes

\footnotetext{
${ }^{78}$ Hammersley (2003) recognized these issues but does not advocate abandoning all uses of interview data. He advised researchers to be aware of the dangers of using interview data and to exercise great caution in interpreting, using and drawing conclusions from them.

${ }^{79}$ According to Akerlind (2005), categories of description for the same phenomena can vary depending on the group of participants and different researchers' ability to develop different categories from the same data. See Akerlind, G.S. (2005b) Variation and commonality in phenomenographic research methods. Higher Education Research \& Development 24(4): 321-334, available at: http://dx.doi.org/10.1080/07294360500284672

${ }^{80}$ Kvale, S. (1996) Interviews: An Introduction to Qualitative Research Interviewing. Thousand Oaks, California: Sage Publications.

${ }^{81}$ Barnacle, R. (2005). Interpreting interpretation: A phenomenological perspective on phenomenography. In J. A. Bowden \& P. Green. (Eds.), Doing developmental phenomenograph, Melbourne: RMIT University Pressm p.47.

${ }^{82}$ Anderberg, E. (2000) 'Word meaning and conceptions: An empirical study of relationships between students' thinking and use of language when reasoning about a problem Instructional Science', Vol.28, available at: http://www.springerlink.com/content/182142t6356h3m31/

Svensson, L., Anderberg, E., Alvegard, C., Johansson, T. (2006a) The interplay between thought and language in understanding problems from a student perspective. In Svensson, L., Anderberg, E., Alvegard, C., Johansson, T. (eds): Pedagogical Reports: The interplay between language and thought in understanding problems from a student perspective. Lund, Sweden: Department of Education, Lund University, p.1-5
} 
made, however I have tried to put my preconceptions of CLE and definition of professional responsibility aside and not to presuppose the view of the participants. My aim during the data gathering and data analysis process was to engage fully with participants' lived experiences to understand their conceptual meanings.

Other limitation include data collected at a certain point in time may not sufficiently represent the perspectives of the entire student population in the law department. Further, due to time constrains, no pilot interviews were used to ensure the questions were phrased clearly. However, it must be acknowledged that although the questions could have been refined, it sufficiently captured the essence of the research.

Data analysis process $^{83}$

In this study, Sjöström and Dahlgren's (2002) data analysis steps were implemented. These are:

1. Familiarisation - To fully comprehend the conceptual meanings of the participants' experiences and to demonstrate reliability between the data obtained and the categories in describing the ways in which a phenomenon is experienced. The interview notes were read three times throughout the process to ensure that the data and categories were linked. ${ }^{84}$ The aim was to look for qualitatively different conceptions of the phenomenon of interest

\footnotetext{
${ }^{83}$ To fully comprehend the conceptual meanings of the participant's experiences, and to demonstrate reliability between the data obtained and the categories in describing the ways in which a phenomenon is experienced, Marton and Booth (1997) and Ashworth and Lucas (2000) advise researchers to deliberately set their opinions and preferences aside in the interpretation of data. Aspects of the validity issue in phenomenographic studies have been addressed comprehensively in Svensson, Anderberg, Alvegard, and Johansson (2006b) and T. Johansson, Svensson, Anderberg, and Alvegard (2006).

${ }^{84}$ Sjöström, B., Dahlgren, L. O. (2002) Applying phenomenography in nursing research. Journal of Advanced Nursing. 40: 339-345
} 
collectively rather than the conceptions of individual participants. ${ }^{85}$ As such, the interview notes were interpreted collectively rather than individually, with cautious awareness of language differences and choice of terminology used during the dialogues. Each participant's dialogue notes were analysed as a whole rather than by way of extracting individual answers from the notes, which helped maintain the intention, expressions and essence of the conversation.

2. Initial grouping - similar emerging themes from the dialogues were grouped together. The result was a number of different groups of data.

3. Comparison of groups/categories: re-reading and re-analysing the data to confirm the initial groupings and then comparing each of the groups to show the differences between them.

4. Labelling categories - Themes were drawn out from each participant's dialogue notes. Similar themes were grouped together to form categories. It must be noted that the epistemological stance taken in this study is that of social constructivism where variations in the way we view the world and what is around us are attributed to our own experiences and existing knowledge. As such, it is acknowledged that the categories for the same phenomena, in this case CLE and professional responsibility can vary depending on the group of participants and different researchers' ability to develop different categories from the same data. ${ }^{86}$

5. Outcome space - The results of the data analysis below has been presented in categories, sustained by quotations from the interviews. The outcome space (table 2) makes a graphical representation of the critically different

\footnotetext{
85 Marton, F. (1994) Phenomenography. in: Husén, T., Postlethwaite, T.N. (eds) The International Encyclopaedia of Education, 2nd edn. Oxford: Pergamon Press, 4424-4429.

86 Åkerlind, G. (2005). Variation and commonality in phenomenographic research methods. Higher Education Research and Development, 24(4), 321-334.
} 
conceptions, understandings and experiences of the participants ${ }^{87}$ and how the categories described correlate together.

\section{RESULTS OF THE STUDY EVALUATING THE EXTENT OF PROFESSIONAL RESPONSIBILITY GAINED}

This paper aims to determine the extent to which students believe they become more aware of professional responsibility and the level of proficiency required for a clinical experience.

The discussion of results presented below is taken from the individual answers obtained from the interviews. The information from the interviews were summarised collectively to obtain the main themes in the dialogue before attempting to preliminary group similar answers, thereby drawing out the categories of description. Attention was given to language differences and choice of terminology used by the participants.

The results of the study demonstrate some useful insights into students awareness of how the CLE experience has helped with development of professional responsibility. The knowledge, skills and values will be discussed below. The challenges faced during the clinical module will be addressed in the reflection section with the aim of identifying enhancements to better utilize the module.

\footnotetext{
${ }^{87}$ Bruce, C., Buckingham, L., Hynd, J., et al. (2004) Ways of experiencing the act of learning to program: a phenomenographic study of programming students at university Journal of Information Technology Education, Vol. 3, p.143-160, available at: http://jite.org/documents/Vol3/v3p143-160121.pdf
} 
Students' awareness of developing knowledge of professional responsibility through application of the law to actual problems

The findings suggest that students believed they were capable of demonstrating knowledge of professional responsibility through the opportunity to develop a clear understanding of how the law applies in a practical context, being able to identity the key areas of legal issues within a case, an improvement in the ability to research the necessary areas of law.

Participant 5: I leant what the day to day life of a lawyer would be like through the integration of practical work in our studies...This experience has helped with improving my level of responsibility, and to think about the skills expected of a lawyer and to use my subject knowledge in practice. It was interesting to learn how the law applies in practice, and in my view it is a common sense approach rather than a straightforward application of legal principles.

Participant 27: I am really proud of myself...I didn't think I had it in me to handle a real case...real client. I was able to resolve the problem for the client in a way that required me to think for myself, research all the necessary law, understand and apply these to the facts and make a decision using all the information I had on the best course of action for the client. I also made decisions on practical solutions based on my knowledge in the area ... and the client seemed very pleased...

Participant 30: When a client comes in with a problem, usually there are a number of issues which need to be addressed - some of which are straightforward, some are practical issues, some are more complex confidence related issues and others are evidential and legal issues. I have learnt to draw out the different types of issues after a preliminary client interview and tackle each one... This was a skill that wasn't easy to master however as I became more familiar with the subject knowledge and procedures, 
it became easier to draw out the issues... Detailed research also helped with this and a better understanding of the application of law was really helpful too... I feel that I have grown to develop these skills over the past year.

Students felt that the clinical experience allowed them to take these skills further to demonstrate improvement in the analysis and application of research to the client's problems and the ability to offer suitable solutions through the process of reasoning and decision making.

Participant 4: ...Being able to explain why one option is better for the client over another requires a fair amount of skills... empathy, research, understanding and reasoning skills. Analysing the documents from the opponents were time consuming and required meticulous fact-finding and strong analytical skills....especially when trying to strengthen our own case.

Participant 7: ... I feel as if I have understood what analytical now means. I used to receive feedback on my assignments saying my work required further analysis, but never really understood what it means, until I began working on this module...I have learnt to break an issue into manageable parts and look in-depth at each part using supporting cases or principles and relevant evidence for and against in order to find solutions for my client... Now I use that skill and process in my assignments too.

Students' awareness of developing knowledge of professional responsibility through learning to solve a client's problem

Most students identified improvement in the process of problem solving as a key skill which improved through the clinical module. Some students explained that that they gained new insights into the application of the law but none were comfortable with 
trusting their own understanding from new knowledge which was being developed and constructed as a result of the experience.

Participant 1: ... learnt how to problem solve properly when I began working in the clinical component of the course. I can confidently say I now know how to identify a client's problem, pick out the legal issues and offer solutions that are both law based and sensible for both sides...

Participant 24: I have understood how to investigate facts effectively, assess the credibility of evidence and present findings logically in a format understandable to the client.

Participant 35: During the negotiations I felt I coped well even when it was necessary to think on my feet and I was only able to do this because of the preparation I had done and having a clear understanding of the case.

Work is also needed across the entire law programme to build in further opportunities for legal research. Being able to exercise appropriate judgement in resolving a client's dispute is an essential skill for a lawyer. Further work is needed in the clinical module and across the full suite of modules in the law programme to embed opportunities for students to undertake reasoning and judgement skills.

Students felt as if the horse was put before the cart in some instances of the CLE experience

Independent research was a key skill demonstrated by all students, although there were varying degrees of corrections and omissions in the work. Students commented that the responsibility of undertaking independent research, and making decisions on offering solutions to clients were the two main challenges they faced because of the lack of experience of exercising academic freedom in other modules. Further 
questioning is needed to gather specific details on why students were not confident in trusting their research and understanding skills.

Participant 22: I took part in the clinical module in my second year and attended to a dispute surrounding a matter of asset division. Because I had not studied Family law and was just beginning to study Land law, I didn't understand the research I was gathering and felt as if I didn't quite learn about the subject area as well as I would have if I was in class. I also felt that because I didn't have any basic knowledge of the two areas of law, my advice to the client was sparse, lacking the credibility of a knowledgeable person.... I doubted myself and checking my notes constantly to make sure I understood what I was saying was correct... I don't think I have learnt much about the areas of law presented by the client but I definitely am a little more confident in taking the initiative to learn something new on my own and to apply new knowledge using my problem solving skills. But I would still prefer a lecture first before attempting to apply my own research.

Participant 25: Learning a new area of law by being thrown into the deep end was challenging but interesting. It made me pay more attention to what I was researching and made me research more deeply into the area to ensure that my research was accurate... but I am not too sure if I actually learn enough of Employment law through this method - I definitely couldn't take an exam and pass it without the traditional teaching.

Students' awareness of their development of some of the lawyering skills of professional responsibility

The findings suggest that students believe the clinical experience has been helpful in gaining insights into making the transition from law school into vocational studies and/or employment. Students also revealed that the clinical experience has been most 
effective in comparison to other modules. Students say that they feel better prepared for work. Further in-depth research is needed to establish the exact reasons and factors which make students feel better prepared.

Participant 10: Most law firms are now looking beyond knowing the substantive law...The clinic has provided me with hands on experience and opportunities to attend court as a Mackenzie friend, represent a client, show evidence of preparation, legal analysis and offering practical solutions. I am confident in gaining employment after my degree.

Participant 27: Feedback on performance or preparation... has really motivated me and encouraged me to pursue a career in law... I have understood the law in a much clearer and substantial manner... Research skills improved and I feel as if I now understand what analysis means - looking into cases and facts in a way that helps discern the key pieces of information. The case I worked on also showed that I have reasoning and decision making skills, which I hope to improve over time, with further legal case work. The evidence suggests that a number of the key lawyering skills of professional responsibility were developed in this module. These include team working, although there were some challenges in appropriate work between team members, problem solving, paying attention to details, reasoning and decision making skills and working responsibly and under pressure to tight deadlines. An assumption can be made based on the office and case management work that students have had to undertake independently, alongside the various skills and research that has been developed over the course of the module.

Participant 13: The clinical experience has given me an employment edge...actual evidence of team working, problem solving, communication with a variety of people, 
business awareness, flexibility and working under pressure; being attentive to detail; willingness to learn and good decision making skills.

Participant 21: I have worked well to deadline and under pressure, and I utilized these strengths in the clinical module... I feel also that I have developed a better approach to problem solving by paying close attention to details in documents such as dates, names of individuals, consistency and discrepancies in multiple pieces of evidence... This has helped me develop a more confident approach to reasoning and explanation skills to clients, supervisors and team members...

The interview however did not delve further into establishing whether there were any improvements to the existing professional skills which students mentioned they had developed.

Student's awareness of their development of lawyering skills through effective, accessible and clear communication

There was good evidence to claim that students understood the effective techniques to establish client rapport, understanding of good questioning and listening in client interviews with the aim of gaining as much details from the client, and knowledge of some effective strategies for use during negotiations. Using this existing knowledge, students felt they were able to plan and execute their own way of dealing with a client.

Participant 7: I listened carefully to my client and understood exactly what he was hoping for. The client was happy with how I kept him updated on the progress I was making. The client preferred telephone calls, so I called him with updates and then followed it up by way of an email for my own records. I think this worked well for both of us. 
Participant 15: The advice I provided my client helped them understand and decide what the right way was forward for them. I also encouraged my client to explore each of the options available to them in a way that benefitted them and helped achieve their goals. I found this challenging but learnt that this is one of the key lawyering skills of a successful lawyer.

From this analysis, it is clear all students were working responsibly and were dedicated to find the best solutions for their clients, however there was insufficient evidence to suggest that students had thorough knowledge of the key values and characteristics of professional responsibility, as identified in table 1 of this paper. Students were capable of demonstrating practical skills alone through their commitment to do right by their clients such as through sound practical application of the law, good research, effective communication and employing good strategies for problem solving.

\section{Students felt they lacked the understanding of what competency actually means}

However, the findings confirm that not all students had this existing knowledge and many went into interviews without planning an agenda or setting out gaols of the task, let alone go in equipped with the knowledge of good practice. There needs to be introductory and refresher workshops highlighting good practice in key lawyering skills, for students to use this as a foundation.

Because of the lack of existing knowledge on good practice, there were many students who felt that they could have been more prepared, anticipating what to expect and as 
such being able to build a better rapport with the client. Most felt they managed to cope well under pressure.

Participant 9: The learning outcomes in this module list number of skills such as competency in case management and competency in developing rapport with client. However, there is no explanation of what competency means and how we could achieve this competency. I would benefit from a set of criteria which explains the levels of competency and during feedback which level I am at to attaining competency of a particular skill. I found it hard to reflect on any improvements without a rubric of some sort.

Participant 21: One of the skills we had to reflect on was our level of competency in understanding and working towards the standard expected of the profession.... We have had a number of lessons and debrief sessions on profession, values, standards, behaviours. ...Reflecting on where I am at on the competency ladder was a challenge as I didn't know what it is to be competent and not competent.

Evidence suggests students were providing appropriate explanation and communication to clients that are meaningfully tailored to client needs, although as already mentioned, there is work to be done within the curriculum on reasoning and judgement skills. Students also commented that they are now more confident in communicating with members of the public and figures of authority for a variety of reasons. This finding does not tell us that clinic made students more competent or skilled after the experience, but it does suggest that clinic was beneficial in developing and improving a range of lawyering and transferable skills.

Students' awareness of their development of values and behaviours of professional responsibility through ethical awareness 
The findings also indicate that there is awareness and demonstrable evidence of students showing sensitivity towards clients.

Participant 11:...I would never have learnt to apply the law to this extent if not for the clinical experience. I developed some good communication skills and had time to consider the conflict between the parties... I also had time to reflect on the extent I have developed my professional skills in particular through the weekly debriefing.

Participant 22: It was really good to use my knowledge to help a client. I improved on my legal research, fact analysis and application skills...I improved in offering practical solutions which has now helped me obtain a training contract.

Participant 31: I grew in confident and became more responsible as I had the welfare of someone else on my hands. There were many instances where I had to question my own belief-especially in the misconduct case-and where I found this to be challenging, I strived to do what is right by my client within the codes of conduct.

Interestingly however, the findings show no link between the clinical experience and a strong desire to serve the community in the context of pro-bono work. This is intriguing because most students had mentioned during their admission to the law programme that they wished to fight for what is right and facilitate access to justice for all. ${ }^{88}$ Possibly, more specific questioning is necessary to form a better opinion on the motivations to support the public through the CLE module.

However, whilst developing competent problems solving skills, there was insufficient evidence to suggest that more often than not students were able to recognise any ethical challenges that may be present in their cases, unless prompted to do so by a

\footnotetext{
${ }^{88}$ Recent work into insights of Pro Bono participation has been undertaken by McKeown, P., (2015) 'Law student attitudes towards pro bono and voluntary work: The experience at Northumbria University, International Journal of Clinical Legal Education, Vol 22 (1) available at: http://www.northumbriajournals.co.uk/index.php/ijcle/article/view/407
} 
supervisor. Nevertheless, it was evident that students took a narrow view in understanding ethical behaviour and legal ethics to mean working in a way that does not contravene the codes of conduct.

Participant 1: ... Applying client confidentiality in the day to day handling of a case really helped me learn how to deal with matters professionally. It gave a much deeper recognition and understanding to ethical practices.

Participant 32: I understand the word ethical to mean doing what is right and moral within the codes of conduct and expectations of a lawyer. I am not sure whether I learnt how to become ethical, but through the debriefing sessions and reflective exercises I had some time to think about how I behaved, how I dealt with a case and I have set out some areas to work on. I do think though that being committed to the client, to the case and to the law is important and that is what being ethical is about perhaps?

Questioning in this area suggested that students were unaware of some of the basic ethical and professional constrains. Initial teaching and refresher workshops in this area are necessary to give students the confidence to identify and address similar issues in the future.

Students felt that it was ok to make mistakes, but most importantly learn from them

It is evident from all students interviewed that being able to reflect critically had helped improve their performance in future lawyering tasks, and students began to identify areas for improvement and set out action plans to achieve their goals. More work is needed to support students through the reflective process to help draw out specific areas of professional responsibility development. 
Participant 24: It is ok to make a mistake, reflect upon it and improve the next time. The reflective questions...helped with establishing priorities and setting out goals for improvement... Considering how you go about acquiring the skills of 'a good lawyer' and how will you know you have achieved your goals helped me focus, draw up a list of what I thought a good lawyer should be, and with feedback...worked towards achieving these skills. The reflective opportunity weekly helped with improvement of how I deal with preparation and clients.

Participant 33: ... Gave me time to reflect on the skills and experience... Opportunity within the module to think hard about my learning and my career goals, based on the experience and feedback on their strengths and how to overcome weaknesses.

Participant 8: The weekly debrief discussion on various skills and professional responsibility...helps us to draw out issues we may not have thought was important. I was able to consider carefully the role of an effective lawyer... to really think about how I engage with clients, undertake research and do the best in each case.

Students were capable of demonstrating the values and behaviours of a lawyer through evidence of their commitment and hard work to do the best for their client as fairly and justly as possible. However further exposure is needed for students to understand the depths of the standard expected of the profession.

Participant 7: I would say being able to research, understand that research, analyse and find solutions for the client are the key skills of a lawyer. Being ethical is important too, but I am unsure what that actually means - probably I will follow the codes of conduct closely.

Participant 12: Communication, analytical and research skills are key components of being a lawyer

Participant 29: Academic intellect, research and finding the right solution are the main skills I would expect from a lawyer 
Most students stated that legal research, analysis and finding the right solution for the client are the top three skills expected of a lawyer. There is no doubt that these skills are vital, work is needed in the clinical module literature to help students understand the wide ranging necessary skillset and characteristics which should be embedded into the learning outcomes of the clinical module and explicitly assessed.

\section{Illustration of variations}

The table below has been created by mapping the findings from the study to the professional responsibility learning outcomes set out above. The table shows the percentage of participants who have gained a range of knowledge, skills and characteristics of professional responsibility. The information presented in the table derives from my interpretation of the themes and learning outcomes contained within the data gathered. 
KNOWLEDGE

Developing new knowledge and

deeper understanding of law through

solving problems

Conducting legal research and

undertaking legal analysis in an

independent and self-direct manner

Resolving client's problem through

effective use of judgement and

reasoning skills

Recognising and understanding

ethical challenges

Understanding of the values,

behaviours, attitudes of a solicitor

LAWYERING SKILLS

Providing appropriate explanation

and communication that is

understandable and tailored to

clientneeds

Working with autonomy and self-

direction to produce work of high

quality

Being well prepared and organised

and being able to think on your feet

Demons

Demonstrating effective client

rapport, interviewing skills,

negotiation skills and analytical skills

of the law and of facts

Exercising appropriate level of

judgement in resolving problems for

clients

CHARACTERISTICS AND BEHAVIOUR

\begin{tabular}{l} 
Coping well with pressure \\
\hline Serving the community
\end{tabular}

Serving the community

about own behaviours and actions to

ensure continuous self-improvement

Showing integrity and sensitivity

Fulfilling the duties of the fidu ciary

Fulning the

relationship

Upholding the
the profession
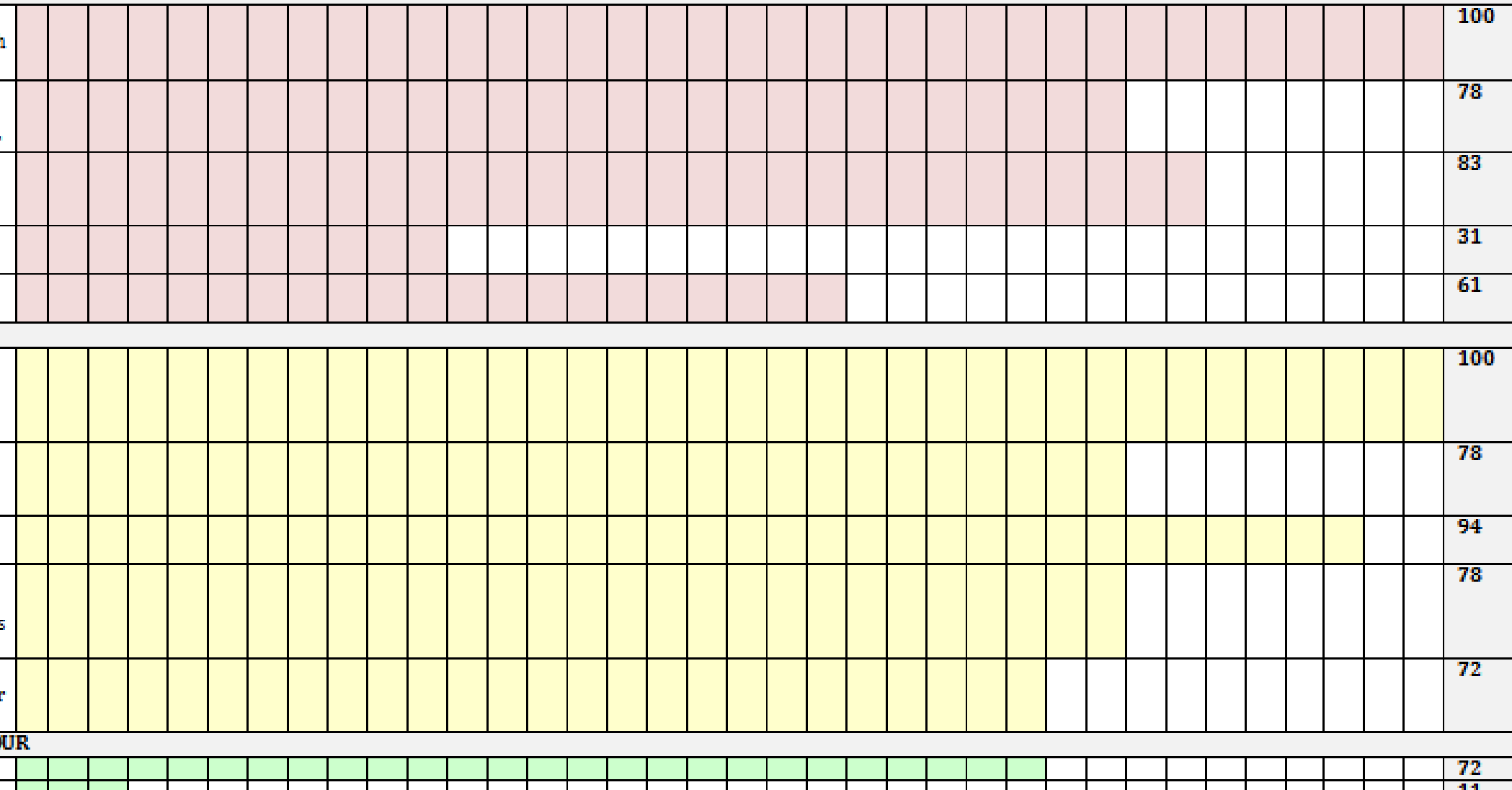

72

.

of

\begin{tabular}{ll|l|l|l|l|l|} 
& & & & & \\
\hline
\end{tabular}

Reviewed Article: Teaching and Learning in Clinic

Table 2: Illustration of the variation in students' learning of professional responsibility after a clinical module 


\section{REFLECTION ON USE OF CLINICS TO CAPTURE THE DEVELOPMENT OF}

\section{PROFESSIONAL RESPONSIBILITY}

1. Guiding students' understanding of learning outcomes and assessment $\underline{\text { measures of a clinical module }}$

A broad brush approach to assessing how competent a student is doesn't capture the extent of their learning from a clinical module. ${ }^{89}$ Instead, clear articulation of what each learning outcome means, how to effectively achieve each of the outcomes and clear assessment criteria to help students understand what is expected of them may encourage students to measure their improvements and become reflective and empowered autonomous learners. ${ }^{90}$

A feedback matrix that recognises the stages and characteristics of professional development such as beginner, competent, proficient and expert ${ }^{91}$ will assist tutors and students to measure competency more effectively and rigorously.

2. Understanding the value of putting the horse before the cart

Clinics alone are insufficient to offer a full critical academic depth of a substantive area of law. However, it should be explained to students on clinical modules that one of the key characteristic of a successful graduate is to show that they are capable of

\footnotetext{
${ }^{89}$ Stuckey (2014), 'Can We Assess What We Purport to Teach In Clinical Law Courses?', Vol. 9 International Journal of Clinical Legal Education, available at: http://www.northumbriajournals.co.uk/index.php/ijcle/article/view/85 Also see: Grimes \& Gibbons (2016) 'Assessing experiential learning - us, them and the others', Special Issue Problematising Assessment in International Journal of Clinical Legal Education, Vol 23(1) available at: http://www.northumbriajournals.co.uk/index.php/ijcle/article/view/492

${ }^{90}$ Stuckey (2014), supra 91.

${ }^{91}$ Daley, B. (1999) ‘Novice to Expert: How Do Professionals Learn?', Adult Education Quarterly, vol.49, available at: $\mathrm{http}: / /$ newprairiepress.org/cgi/viewcontent.cgi?article=1998\&context=aerc
} 
independently learning and applying new knowledge accurately. Within the context of professional responsibility, a future lawyer should be able to demonstrate and exercise a high level of autonomy in professional settings. To facilitate this, clinics are well-suited for giving students opportunities to demonstrate and develop the ability to work autonomously, by demonstrating a variety of lawyering skills, to complement the attainment of subject matter knowledge.

3. Adopting a living education theory framework of learning and assessment in clinical modules

The art of learning to become professional or responsible or ethical will only be possible if the learning is structured in a way that facilitates and draws out these specific intended learning outcomes within a module. In the context of a clinical setting, the most effective way to learn from experience is to use a process of '.... selfreflective inquiry ... to improve the rationality of their own... practices, their understanding of these practices, (and) the situations in which the practices are carried out... The analysis which follows is focused upon the nature of the validity of an individual claim to know his or her own professional development'. ${ }^{92}$ This process is known as living theory which immerses the practitioner into the mind-set of 'How do I improve my practice?'. ${ }^{93}$

\footnotetext{
92 Whitehead, J. (1985) An analysis of an individual's educational development - the basis for personally orientated action research. Published in Shipman, M. (Ed.) Educational Research: Principles, Policies and Practice, p.97-108; Falmer; London, p.97. For more recent work see Whitehead, J. (2009) Self-study, Living Educational Theories, and the Generation of Educational Knowledge, Studying Teacher Education, 5(2); p.107-11.

${ }^{93}$ Whitehead, J. (1989). Creating a Living Educational Theory from questions of the kind, 'How do I improve my practice?', Cambridge Journal of Education, 19, 41-52, available at: http://actionresearch.net/writings/writing.shtml
} 
This framework begins with what students know about how they come to acquire new knowledge from actively engaging in practical and professional work ${ }^{94}$ For example, the knowledge in this context may involve information about how lawyers should conduct themselves in a fact finding interview or in a negotiation, the rules governing civil or employment practice, key skills such as building a rapport of trust and confidence with clients, questioning techniques in interviews and strategies of achieving goals in negotiation.

The findings from this study indicate that further work is needed prior and during the clinical experience to give students adequate knowledge to understanding the depths of the standard expected of the profession, which should be embedded into the design of the clinical module with clear learning outcomes to be reflected upon and assessed. As such, there needs to be some introductory theoretical sessions on good practice of key lawyering skills, values and characteristics which will help students learn how to become competent in performing a task. Then, the student will be guided to articulate a plan for how they intend to perform a particular skill. This knowledge can be used to compare the performance actually exhibited.

After a clinical session, it would be useful to hold a peer debrief to share experience between students on how the actual performance related to the planned performance,

\footnotetext{
${ }^{94}$ Whitehead, J. \& McNiff, J. (2004) Ontological, epistemological and methodological commitments in practitioner-research. Paper presented at the BERA Symposium 2004 in Manchester on: "Have We Created A New Epistemology For The New Scholarship Of Educational Enquiry Through Practitioner Research? Developing Sustainable Global Educational Networks Of Communication
} 
discuss differences and what the student would try to do differently the next time. A checklist to guide the discussion could include technical lawyering skills, ethical and emotive issues, and specific discussions on professional responsibility. If the performance demonstrated was incompetent, a feedback session with the tutor/supervisor can analyse what caused the ineffectiveness, the student's skills, values, or knowledge demonstrated.

This process of embedding continual planning, acting and reflecting within the clinical module provides a basis upon which students can evaluate their performances leading to practical change. ${ }^{95}$ Furthermore, the ability to reflect critically on one's own knowledge and skills is vital ${ }^{96}$ especially if we accept the pedagogic rationale of experiential learning where learning is seen as an active, self-constructed and intentional process. ${ }^{97}$

This also allows for new knowledge to be formed, opportunity to test and refine a theory and thereby continually improve one's performance. Hammersley (1993) encapsulates this type of learning process as "sound practice cannot amount to the

\footnotetext{
${ }^{95}$ Quigley, A. \& Kuhne, G (1997) ‘Creating practical knowledge: Posing problems, solving problems and improving daily practice', New Directions for Adult and Continuing Education. No.73. San Francisco, CA : Jossey-Bass..

${ }^{96}$ England and Wales Solicitors Regulation Authority, outcomes statement of 2011: www.sra.org.uk/documents/students/lpc/Outcomes-Sept2011.pdf. The 2013 report on the Legal Education and Training Review can be found at: http://letr.org.uk/

${ }^{97}$ Leading work on experiential learning can be seen in Healey, M. \& Jenkins, A. (2000) Kolb's Experiential Learning Theory and Its Application in Geography in Higher Education, Journal of Geography, 99, pp.185-195. Original advocate of experiential learning is Kolb, D.A. (1984) Experiential Learning: Experience as the Source of Learning and Development, Prentice-Hall, Inc. Englewood Cliffs, NJ.
} 
straightforward application of theoretical knowledge, but is an activity that necessarily involves judgment and draws on experience". ${ }^{98}$

In many instances, the findings from this study indicate the effectiveness of the time, space and guidance provided to reflect. Reflective practice of involving 'How I can improve' is designed to entrench learning from experience by assisting students to think critically on the basis of experience and feedback, to improve the continuing work on behalf of the client and help students to understand the qualities of their work to date and what to do to improve those areas which are less developed. ${ }^{99}$ Bergman suggests that reflections can expose students to new understanding in a constructive and explicit way, rather than just hoping that students will absorb the important lessons of how to behave in a professionally, ethically and responsibly simply through a clinical experience. ${ }^{100}$ As such, it has been argued that the need to embedded reflective practice is a developmental path to a higher level of professionalism. ${ }^{101}$ The clinical module featured in this study requires students to write a detailed reflective ${ }^{102}$ account about preparation for a task, how they performed and how they intend to improve taking into account the theory of practice. In this paper, the findings have shown that students have begun to develop critical thinking about their

\footnotetext{
${ }^{98}$ Hammersley, M. (1993) ‘On practitioner ethnography' in Hammersley, M. ‘Controversies in Classroom Research. Buckingham: Open University Press, p. 430)

${ }^{99}$ The best known work on reflective learning in a professional context is by Schon who created the term 'reflective practitioner' - supra 11

${ }^{100}$ Bergman, P. (2003), supra 18, p.109

${ }^{101}$ Leering, M (2014) 'Conceptualizing Reflective Practice for Legal Professionals', Journal of Law and Social Policy, p.99-100, available at: http://digitalcommons.osgoode.yorku.ca/cgi/viewcontent.cgi?article=1191\&context=jlsp 102 Hyams, R., (2010), supra 30
} 
performance and methods to continuously improve.

Some of the generic questions students were asked to reflect on at the start of the module and then to evaluate this at the end of the module include questions such as:

- What do you understand by the term 'a good lawyer'?

- What sorts of skills should a 'good lawyer' possess?

- How is 'a good lawyer' different from 'a lawyer'?

- Do you possess these skills?

- How will you go about acquiring the skills of 'a good lawyer'?

- How will you know you have achieved your goals?

However, from reflecting on the findings, it is proposed that a more constructive approach to reflection would help to explicitly draw out the key learning outcomes of professional responsibility. Constructive reflection is built on the premise that learning is an active process, necessarily situated to construct knowledge ${ }^{103}$ rather than acquiring it through a detailed and guided cycle designed to assist the students in deeper and more personalized engagement of learning. From reviewing the findings, a proposed constructive reflection cycle has been illustrated in table 3 .

Constructive reflection requires the active role of the tutor to help students construct knowledge. ${ }^{104}$ Tutors are encouraged to provide clear questions or statements aligned to learning outcomes which creates a robust framework for students to question

\footnotetext{
${ }^{103}$ Dewey, J. (1938) Experience \& Education. New York, NY; Vygotsky, L. (1978), Mind in society: The development of higher psychological processes. Cambridge, MA: Harvard University Press. 104 Vygotsky, L. S. (1978). Mind in society: The development of higher psychological processes. Cambridge, MA: Harvard University Press. p.58
} 
themselves and their strategies, formulate ideas, action plans for improvement after the clinical process. Through the constructive guidance, students are able to construct their knowledge actively, aligned to the aims and outcomes of the module.

As such, it would be useful for students to use the professional development matrix designed in table 1 of this paper against which to evaluate themselves. ${ }^{105}$

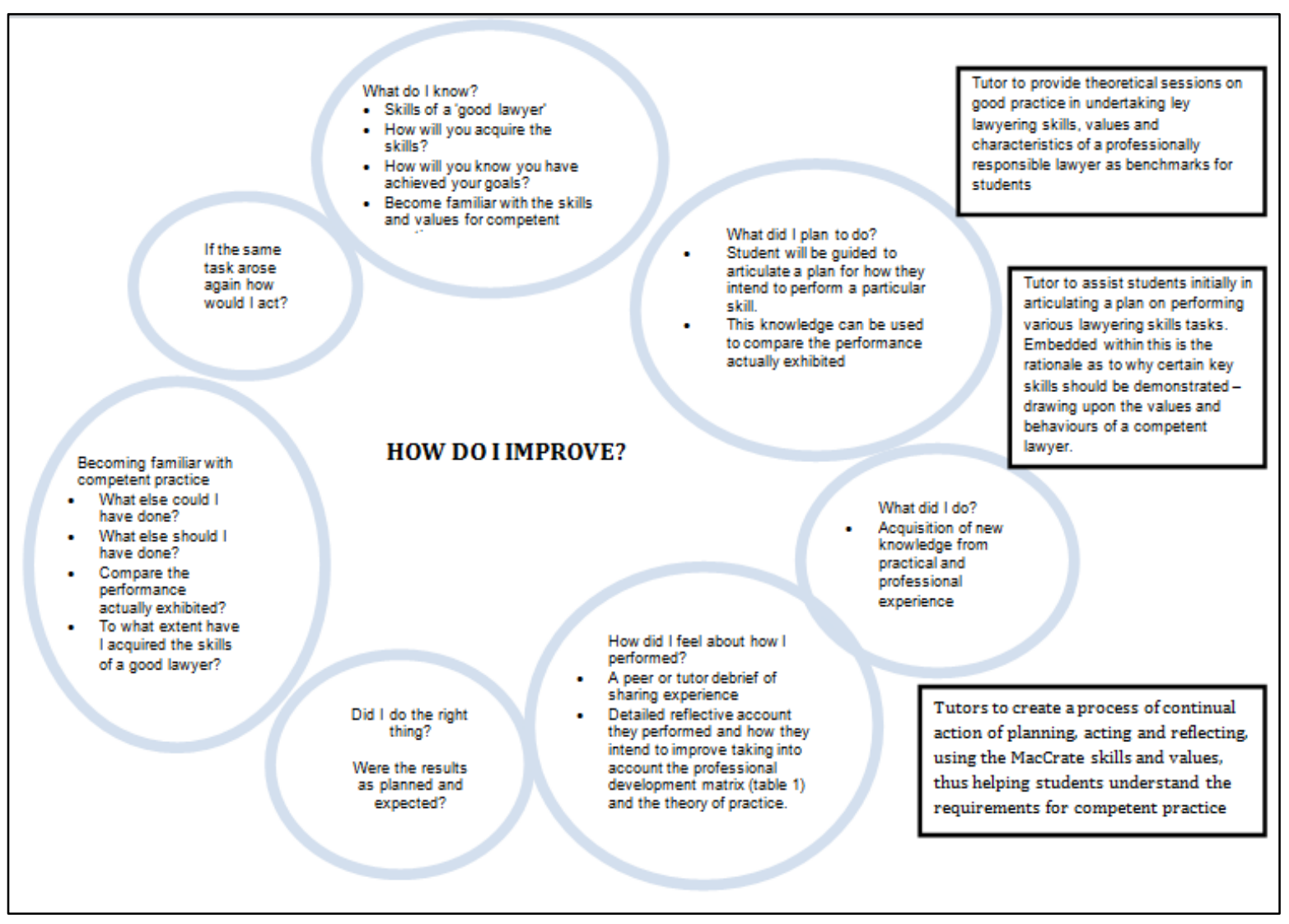

Figure 1: Framework of embedded reflection in a clinical module

Students will be directed to identify the skills and values of a good lawyer as currently being required, but more specifically using the skills and values now identified as key components of professional responsibility. This will help serve two purposes: It will

\footnotetext{
${ }^{105}$ See table 1 on pg.7 of this paper which comprises of the fundamental knowledge, skills and characteristics of professional responsibility.
} 
enable students to develop the life-long skill of self-reflection and continual improvement and it will give students the opportunity to become familiar with the requirements for competent practice. ${ }^{106}$

\section{For academics integrating skills and values throughout the law curriculum}

Here are some thoughts which may help programme leaders to consider when thinking about how to integrate and embed relevant skills and values into the curriculum.

- Undertake a skills audit within the law programmes to determine gaps in the teaching of the components of professional responsibility ${ }^{107}$

- Identify three sets of top 5 skills and values to integrate into each year of the law programme. This study indicates that further work is needed in the clinical module and across the full suite of modules in the law programme to embed opportunities for students to undertake reasoning and judgement skills in particular.

- Consider the steps that will be put in place to bridge the gaps identified. This study indicates that initial teaching and refresher workshops on professional responsibility are necessary to give students the confidence to identify and address similar issues in the future. It is also necessary to highlight good practice in key lawyering skills.

\footnotetext{
106 The MacCrate report, supra 7, The Carnegie report, supra 16 and The Best Practice report, supra 38. ${ }^{107}$ In Section C of recommendation 8, the MacCarte report recommends law schools to undertake a skills audit to determine which of the skills and values described in its Statement of Skills and Values are presently being taught in its curriculum.
} 
- Reflect on whether the skills and values of professional responsibility are taught across the programme and how they are taught. Findings indicate that it is helpful for students to understand the learning outcomes and how they will be taught and assessed.

- Reflect on whether these skills and values can be gained through experiential learning

- Develop relevant support for students to draw out the learning gained from experiential learning, in particular the characteristics of professional responsibility.

- Consider how personal development activities enhance the overall skills and values training?

\section{CONCLUSION}

The aim of this study was to examine whether CLE as a learning methodology can successfully facilitate the development of students' awareness of professional responsibility in law students. Although there is a rich repository of literature in this field, there is little in the way of empirical data evaluating the link between utilizing CLE to develop specific skills. The study employed a phenomenographic methodology to evaluate the variations in student learning and presented findings which suggest that clinics have the capability of developing and enhancing a variety of lawyering skills, awareness of values and characteristics of a competent lawyer and 
facilitate the development of new knowledge and deeper understanding of the application of law.

The findings from this study show that students believed they had acquired learning and acquisition of knowledge, skills and character building during the clinical experience and their comments demonstrate a greater awareness of this. ${ }^{108}$ The findings suggest that students learned most effectively through:

- understanding and applying the law in actual problems;

- learning from mistake made;

- making mistakes and learning from it;

- developing confidence in some key lawyering skills such as learning to solve a client's problem;

- communicating clearly in an accessible manner with clients and stakeholders;

- and in a small number of situation identifying ethical considerations within a client's problem.

There is some indication from the study that students believe they have developed greater awareness of professional responsibility such as working autonomously, learning to deal with uncertainty and emotions, working with integrity and confidence. There is also some evidence of a sense of professional identity and some sense of attitudes, moral and ethical practicalities in legal practice. Despite students' awareness of this high quality learning, they were unable to confirm whether they

\footnotetext{
${ }^{108}$ However, this paper did not seek to make an assessment of whether students' learning of professional responsibility actually had developed.
} 
were approaching a competent professional standard, including not understanding what competency means within the context of various skills and values and undertaking practical work without adequate knowledge of the substantive law.

The study concluded by offering a reflection on how clinics could be better utilized to constructively capture all the opportunities to develop professional responsibility. These reflections include thoughts on guiding students to understand the learning outcomes and assessment measures of a clinical module, guiding students to understand the value of putting the horse before the cart, designing a clinical module around a living theory framework as identified in Table 3 of the paper on, whilst embedding reflections in a constructive and structured manner in the clinical module. With the ongoing research in this field, some key areas are in need for future research:

- Whilst it is acknowledged that employing a suitable methodology could be challenging, it is proposed that clinicians and academics could describe and measure how effectively their clinics achieve the intended outcome and aims of a clinical module. This will offer valuable insight into the real educational value of CLE and establish its link between various skills development through this learning methodology;

- Develop a level of competency feedback matrix that is meaningful for students; ${ }^{109}$

\footnotetext{
109 There is already some work on this has been undertaken by Gold, N. (2015), supra 1; Stuckey (2014), supra 4 and Grimes \& Gibbons (2016) supra 91
} 
- Develop effective methods of embedded reflection in clinical courses throughout a variety of stages of the clinical experience to actively draw out students' development of professional responsibility;

- Constructively aligning elements of professional responsibility to the learning, teaching and assessment in clinical modules using the living theory framework; Finally, the paper concludes by offering some thoughts on what all of us could do to integrate skills and values throughout the law curriculum. Personally, these reflections will help me redesign and enhance the existing module and I hope that there is some value in this for other clinical modules. 